\title{
Understanding the Learning Models Design for Indonesian Teacher
}

\author{
Ira Irviana \\ Makassar Islamic University (UIM Makassar), Indonesia \\ *e-mail: irairviana90@yahoo.com
}

\section{Article Information \\ Received: August 08, 2020 \\ Revised: August 16, 2020 \\ Online: September 03, 2020}

\begin{tabular}{l}
$\frac{1}{\text { Keywords }}$ \\
\hline $\begin{array}{l}\text { planning of learning, learning } \\
\text { design, learning model }\end{array}$
\end{tabular}

\begin{tabular}{l} 
ABSTRACT \\
\hline This paper aims to understand how a teacher designs a \\
learning model. Many writings discuss models oflearning, but \\
can not be applied in a learning process. This paper is expected \\
to provide teacher experience in planning and learning \\
through development models. Planning is essential because it \\
is a managerial process to determine what to do and how to \\
do it, and the goals to be achieved and work programs \\
developed to achieve goals. Therefore, learning planning is a \\
decision-making process resulting from reasoning about \\
specific learning goals and objectives, namely behavioral \\
changes and a series of activities that must be carried out to \\
achieve thesegoals by using all existing potential and learning \\
resources. By integrating a study, one can see the types of \\
material that have a relationship with each other, e.g., \\
learning characters and morals that, if studied, will lead to \\
one point, namely a good personality. More generally, there \\
are moral and character values when integrating fields of \\
study, such as the field of religious education and character \\
integrated with the field of civic education. Materials can be \\
selected in learning to integrate several types of development \\
models, including ASSURE, ADDIE, Jerold E. Kamp, et al., Dick \\
\& Carey, and Gerlach\&Ely.
\end{tabular}

\section{INTRODUCTION}

A lesson 's primary goal is to change and increase students ' abilities. Learning goals will be achieved to the maximum if it starts with a plan because without properly planning activities, it can turn into a mess. After all, we do not have an overview and management of the activities to be carried out(Hisbullah, 2020). The education system is a series of sub-systems or elements of education that are interrelated in realizing its success, where there are goals, curriculum, materials, methods, educators, students, tools, tools, and approaches (Ilham, 2020). Therefore, in learning activities, for teachers to prepare everything through planning, learning activities is something that must be done for the success of learning to be carried out.

The learning model is a plan or a pattern that is used as a guide in planning classroom learning. The learning model refers to the learning approach that will be used, including teaching objectives, stages in learning activities, learning environment, and class management (Trianto, 2013). Furthermore, Trianto added that the learning model is a conceptual framework that describes systematic procedures for organizing learning experiences to achieve specific learning objectives, and has a function as 11 guidelines for learning designers and teachers in planning and implementing teaching and learning activities (Trianto, 2017).

There are several classroom action types of research discussing the advantages of an application of a learning model to improve student learning outcomes. One of them explains that using a learning model in the learning process in the classroom increases student motivation and learning outcomes so 
that learning becomes more active (Hisbullah \& Firman, 2019). Therefore, it can be concluded that the learning model is a conceptual framework that describes a systematic procedure for organizing learning experiences to achieve specific learning objectives (Alannasir, 2020) and serves as a guide for instructional designers and teachers in designing and implementing the teaching and learning process.

\section{Planning of Learning}

Planning is the initial activity in every action that is carried out later, whether it is carried out in writing, or only in someone's thoughts (Ananda, 2019). Kast and Rosenzweig explained that planning is the process of deciding in advance, what will be done, and how (Sijatri, 2010). Planning includes the entire mission, identification of critical results, and setting specific goals as well as developing policies, programs, and procedures to achieve these goals.

Planning, in a pure sense, can be explained as a process of preparing things that will be done in the future to achieve a predetermined goal. Planning is the process of preparing and determining the goals and methods that must be taken to achieve the stated goals (Rosyadi \& Pardjono, 2015). In planning the teaching of learning, the Indonesia teacher must pay attention to the learning system that will cover all actions from the teaching and learning process (Baharuddin, n.d.; Suryapermana, 2017). Therefore, if the implementation of the teaching and learning process is outside and away from the system, then whatever the Indonesia teacher hopes and pursues in learning activities will only reap failure and suffering, and this is the beginning of disaster in the world of education. Based on the explanation above, it can be understood that planning has four elements that surround it. The four elements are: (1) the existence of goals that must be achieved, (2) the existence of a strategy to achieve the objectives, (3) resources that can support, and (4) the implementation of each decision.

A process learning carried out by teachers in guiding, assisting, and directing students to have a learning experience. In other words, learning is a way of preparing learning experiences for students (Nadlir, 2013). Learning activities are related to how teachers teach and how students learn. In this case, learning is an activity that is realized and planned, which involves three things, namely, planning, implementation, and evaluation (Ilham, 2020; Qasim, 2016).

Ki Hajar Dewantara stated that learning was nothing but a part of education. Learning is nothing but the goal of education by providing knowledge or knowledge and skills (Shawmi, 2015). Also, learning is a learning and teaching interaction that takes place as a process of mutual influence between teachers and students, where between the two there is a relationship or communication of interaction, namely teachers teaching on the one hand and students learning on the other (Pane \& Dasopang, 2017).

Furthermore, learning is a series of events that are planned to be delivered, to activate and encourage student learning, which is the process of assembling a learning situation (consisting of classrooms, students, and curriculum materials) to make learning easier (Fathurrohman, 2017). Furthermore, it is explained that learning is an interactive relationship between teachers and students, in this case, the teacher creates situations and conditions so that students can actively learn, through this interaction an active teaching-learning atmosphere or process will arise. Each student is busy learning and carrying out the assigned task by teachers (Simbolon, 2014).

From the previous explanation, it can be concluded that learning planning is a decision-making process as a result of reasoning about specific learning goals and objectives, namely changes in behavior and a series of activities that must be carried out to achieve these goals by utilizing all existing potential and learning resources.

\section{METHODS}

The research method used in this study is library research done by collecting articles or scientific papers related to learning planning, learning design, learning model. This research is qualitative, by observing phenomena in Indonesia, formulating problems that occur, and then related to the obtained literature. Data collection techniques are performed by tri-formulating (combined) literature review by collecting data, particularly verbal data, through books, articles, notes, and various other scientific literature. The data collected are then analyzed inductively to produce grounded theory, a theory that emerges from non-hypothesis data. Writing steps to prepare this article: 1) Choosing a problem; 2) a preliminary study; 3) formulating a problem; formulating objectives; 4) conducting a study; 5) making 
a discussion; 6) formulating conclusions drawn from analysis results and recommendations for other authors.

\section{RESULTS}

\section{Integration of Learning Models}

\section{Technology Integration of Teacher Learning}

Information and Communication Technology (ICT) is a term used to describe an exciting and innovative way to provide lifelong learning with global access to information, learning, and support (Fitriyadi, 2013). Anderson revealed that ICT includes many technologies that allow us to receive information and communicate or exchange information with other people, with devices and functions (Al-Maarij, 2019). In this case, ICT includes communication devices or applications, including radio, television, cellular telephones, computer and network hardware and software, satellite systems, as well as various services and applications related to them, such as video conferencing and distance learning. At the UNESCO consensus 2011, there was a consensus on the benefits to education through the appropriate use of ICT developments. The fundamental issue is whether teachers know how to use ICTs effectively in their teaching. How ICTs are used will depend on the subject being taught, the learning objectives, and the nature of the student. ICTs offer a fast-growing and attractive learning environment, blurring the boundaries between formal and informal education and inviting teachers to develop new ways of teaching and enabling students to learn.

With an ICT-based system, it will improve the quality of education for students in increasing motivation, facilitating the acquisition of necessary skills, promoting investigation and exploration, and preparing individuals for the impulses of the technological world. There are several benefits of using ICT in learning, namely as follows:

a. Learning materials are developed anywhere and can be accessed by students anywhere

b. Reducing physical barriers to access to learning, minimizing travel and living costs, and distance is no longer a determinant of marginalization.

c. Use of a network of teachers and advisors to structure processes and distribute ideas and materials to a broader audience

d. Interactive systems can generate formative data on learning progress and link to adaptive learning according to student needs

e. Students from different locations can learn and share learning resources

f. Teachers from different places and with different perspectives can share experiences and jointly develop learning resources

2. Integration of Science Literacy Against Teacher Learning

The relationship between science learning and scientific literacy can be seen from two steps, namely (1) science learning clarifies scientific literacy, which is said in general, (2) science learning helps science to be more valuable. The implementation of science learning involves an integration process that includes material content, processes, and skills. Integration content must be carried out in full through the learning process through methods, teacher readiness, experimental activities, facilities, and infrastructure (Baderiah \& Ilham, 2019; Diah, 2020). Furthermore, science is a form of integration from the fields of biology, physics, chemistry, and biology, which are linked through each of the concepts contained in each field (Situmorang, 2016).

Implementation in science learning is in the spotlight of the government, which makes science learning must be contextual and based on problems related to everyday life. Depdiknas (2007) classifies science into three aspects, namely (1) life and health, (2) the earth and the environment, and (3) technology. The process of implementing science learning is, of course, inseparable from the nature of science. According to the Ministry of Education and Culture (2011) that at the teaching level, science must be able to build concepts from natural phenomena. Furthermore, science learning must follow an exact pattern in order to improve scientific thinking. Science learning must develop a scientific attitude. Then science learning must link the theoretical concepts to everyday life.

Based on the nature of science, of course, a science teacher must pay attention to the potential of their students by increasing interaction with science objects through experiments, practicums, or science experiments. The implementation of science learning, which contains the essence of science itself becomes a separate asset for each teacher to equip students with scientific literacy. Therefore, 
teachers must study and map the competences of science subjects, which will be integrated with scientific literacy-assessing and determining activities aimed so that teachers can get a comprehensive picture of science learning activities for the achievement of necessary competencies. In carrying out integration, it is necessary to pay attention to indicators of scientific literacy. According to Miller, scientific literacy is divided into three major parts, namely the understanding of citizenship, praxis, and culture, all of which are complementary to produce a holistic understanding (Ingtias, 2016). Meanwhile, the evaluation process in literacy can include higher-order thinking investigations.

In the aspect of the scientific process, Schwab (2009) explains there are five indicators, namely: (1) describing scientific phenomena, (2) explaining scientific phenomena, (3) predicting scientific phenomena, (4) understanding scientific investigations, and (5) interpreting and concluding based on scientific evidence (Situmorang, 2016). Therefore, it is necessary to conduct an assessment of the material to maximize the ability of students so that the process of understanding scientific studies can be realized. The scientific process in the form of searching for, interpreting, and analyzing facts/data is a form of activity that has the potential to train students' scientific literacy to determine indicators, subject matter, learning models, and the type of evaluation used. The integration of scientific literacy in science subjects is an important variable that must be started to be prepared.

3. Integration of Character Education in Teacher Learning

Responding to several weaknesses in the implementation of morals and character education (character education), primarily through the two subjects of Religious Education and Citizenship Education, innovative character education has been pursued. These innovations are as follows:

a. Character education is integrated into all subjects. The integration includes loading values in all subjects and implementing learning activities that facilitate the practice of values for all subjects in and outside the classroom.

b. Character education is also integrated into the implementation of student development activities.

c. Also, character education is carried out through the management of all affairs in the school, which involves all school members (Dianti, 2014).

Of the three forms of innovation above, the most important and directly in contact with daily learning activities is the integration of character education in the learning process. The integration of character education through the learning process of all subjects in schools is now one of the widely applied models. This model has pursued with the paradigm that all teachers are character educators so that all subjects are also assumed to have a mission in shaping the noble character of students (Hendrowati \& Suningsih, 2018). In addition to this model, there are also other models in character education in schools, such as the subject matter model in the form of its subjects, namely making character education a separate subject so that it requires a separate formulation of content standards, competency standards, and essential competencies, syllabus, RPP, teaching materials, learning strategies, and assessments at school. This model is not easy to implement and will add to the burden on students who have been given so many subjects. For this reason, the integration model of character education in subjects is considered more effective and efficient than the subject matter model.

\section{Learning Development Models}

\section{ASSURE model}

Before knowing further what the ASSURE model is, this paper first describes the learning model. According to Abdul Majid, the model is defined as a conceptual framework used to guide activity. Dewey (Joyce \& Weil) in Abdul Majid defines the learning process as' a plan or pattern that we can use to design face - to - face teaching in the classroom or tutorial setting and shape instructional material' (a plan or pattern that we can use to design face - to - face classes or additional learning outside the classroom and to sharpen teaching materials)(Majid, 2014).

Based on this thought, the learning model is a conceptual framework and systematic procedures for organizing learning experiences to achieve specific learning goals, and serves as a guide for teaching designers and teachers in planning and implementing teaching and learning activities. Thus, teaching and learning activities are truly purposeful and systematically organized. Meanwhile, the ASSURE model, according to Afandi and Badarudin, is a model which is a formulation for Teaching and Learning Activities (KBM) or also called a class-oriented model. The ASSURE model is one of the guidelines and plans that can help to plan, identify, determine goals, choose methods and materials, and evaluate 
(Afandi \& Badaruddin, 2011). Sharon Smaldino developed the ASSURE model, Robert Henrich, James Russell, and Michael Molenda in their book 'Instructional Technology and Media For Learning,' which is currently being translated into Indonesian and published by a publisher in Indonesia. Some of the benefits of the ASSURE learning design model (Prawiradilaga, 2009) include:

a. Simple, relatively easy to implement

b. Because it is simple, the instructor can be developed himself.

c. The components of teaching and learning activities are complete.

d. Learners can be involved in the preparation of teaching and learning activities.

Learning using the ASSURE model has several stages or steps that can help achieve useful and meaningful learning for students. These stages by Smaldino et al. he called the ASSURE model, which stands for the components or necessary steps contained therein, including:

a. A: Analyze Learner (analyze the characteristics of students)

b. S: State Standards And Objectives (set standards and learning objectives)

c. S: Select Strategies, Technology, Media, and Materials (choosing strategies, technology, media, and teaching materials/materials)

b. U: Utilize Technology, Media and Materials (using technology, media, and learning materials)

a. R: Require Learner Participation (activate the involvement of students)

c. E: Evaluate and Revise (evaluate and revise)

The advantages of the ASSURE model are as follows:

a. These components include student analysis, formulation of learner objectives, learner strategies, delivery systems, assessment of learning processes, and learning assessments.

b. They often held remedially. Also, this model promotes students in terms of the learning process, learning types, prerequisite abilities.

c. Small groupings are held, such as grouping students into independent learning and team learning. It implies that educators to deliver material and manage class activities

d. Educators can be applied to this model themselves

The disadvantages of the ASSURE model are as follows:

a. Does not cover a particular subject

b. Although there are relatively many components, not all components of the learning design are included.

c. This model emphasizes the delivery of material and classroom management.

d. Other aspects that have an impact on the learning process are not detected

e. This model is used to guide an educator in how to manage and create teaching and learning interactions

f. To be able to motivate proper learning

g. In order for educators to be more creative and, cooperation between educators and students can be developed well with this KBM model.

2. ADDIE model

According to Benny A. (2009), there is one learning design model that is more generic, namely the ADDIE (Analysis Design-Develop-Implement-Evaluate) model (Sari, 2017). ADDIE emerged in the 1990s, developed by Reiser and Molenda. One of ADDIE's functions is to become a guide in building training program tools and infrastructure that are effective, dynamic, and support the training performance itself. This model uses five stages of development, namely:

a. Analysis (analysis)

b. Design (design / design)

c. Development (development)

d. Implementation (implementation / execution)

e. Evaluation (evaluation / feedback)

This product development steps, research, and development model is more rational and more complete than the 4D model. This model has similarities with the database system development model previously described. The core activities at each stage of development are almost the same. Therefore, this model can be used for various forms of product development, such as models, learning strategies, learning methods, media, and teaching materials. The advantages of the ADDIE model are that it is simple and easy to learn and its systematic structure. As we know that the ADDIE model consists of 5 
components that are interrelated and structured systematically, which means that from the first stage to the fifth stage in its application, it must be systematic, it cannot be sorted randomly or we can choose which one we think we want first. (Astuti et al., 2017). Because these five stages/steps are straightforward when compared to other design models. It is simple and systematically structured so that educators will efficiently study this design model.

The weakness of the ADDIE model is that the analysis stage takes a long time. In this analysis stage, the designer/educator is expected to be able to analyze the two components of students first by dividing the analysis into two, namely performance analysis and needs analysis (Fitriyani \& Rosalia, 2018). The two components of this analysis will later affect the length of the process of analyzing students before the learning stage is carried out.

3. Jerold E. Kamp, et al. Model

Learning Planning Jerols E. Kemp of California State University in Sanjose developed the earliest Instructional Development model for education. The Kemp learning model guides the wearer to think about everyday problems and teaching goals. This model also directs instructional design developers to see the characteristics of students and determine appropriate learning goals. The next step is to specification the lesson content and develops a pre-test of the objectives that have been set. Next is to define strategies and steps in teaching and learning activities and learning resources to be used.

Furthermore, the material/content (content) is then evaluated based on the objectives that have been formulated. The next step is to identify and revise based on the results of the evaluation (Rusman, 2012). The Kemp model learning design planning can be used at the primary, secondary school, and college levels. The Kemp model learning design is designed to answer three questions, namely:

a. What should students learn?

b. What / how is the procedure and what learning resources are appropriate to achieve the desired learning outcomes (desire, media, and learning resources used).

c. How do we know that the expected learning outcomes have been achieved (evaluation)?

Kemp says learning design has many interconnected parts and functions to accomplish the desired. Kemp's instructional model is revolving. According to Kemp, each development step involves revision as it starts at any point in the cycle (Kariadinata, 2020). Kemp model development lets developers start from any component. However, because Indonesia's national curriculum is goaloriented, the development process should start from the goal. Kemp developed the earliest education design model. The Kemp model guides students about everyday problems and learning goals. This model also directs instructional design developers to see student characteristics and determine appropriate learning goals. The next step is to specify the lesson and develop a pre-test of set goals. Next, identify strategies and steps to be used in teaching and learning activities and learning resources.

Furthermore, the material/content (content) is then evaluated based on the objectives that have been formulated. The next step is to identify and revise based on the evaluation results. The importance of this discussion is that we can understand how the J.E Kemp model of learning can be applied in the learning process in the classroom.

According to Kemp, learning design consists of many interconnected components and functions and must be done logically to achieve what is desired in order to be oriented towards a comprehensive learning design. So that elementary and middle school teachers, college lecturers, trainers in the industry, and media experts will work as instructional designers. The Kemp model is an approach that prioritizes a flow that is used as a guide in the preparation of program planning, where the flow is a systematic series that connects the objectives to the evaluation stage. The components in this Kemp learning model can stand alone so that at any time, each component can be revised. The stages in developing learning tools according to the Kemp model (Defina, 2018), namely:

a. Instructional Problems; At this stage, a goal analysis is carried out based on the learning problems contained in the curriculum that applies to the study material that will be developed by the device.

b. Learner Characteristics; At this stage, an analysis of the characteristics of the students will be carried out as the place for implementing the device. The characteristics referred to include traits, abilities, and experiences both as individuals and as groups. Sources for obtaining student characteristics include teachers, school principals, or relevant documents-personal characteristics such as age, attitude, and persistence towards lessons. 
c. Task Analysis; Task analysis is a breakdown of course content in the form of an outline to master the content of the study material or learn skills that include cognitive skills, psychomotor skills, and social skills. This task analysis includes content structure analysis, procedural analysis, concept analysis, and information processing. Content structure analysis is carried out by looking at the curriculum, while procedural analysis is an analysis of tasks carried out by identifying the stages of task completion in order to obtain a task map. Concept analysis is carried out by identifying the main concepts to be taught and arranging them systematically according to the order of presentation and detailing the relevant concepts. The results of this analysis will obtain a concept map. Information processing analysis is carried out to classify the tasks that will be carried out by students during learning by considering time allocation. This information processing analysis will produce coverage of concepts or tasks to be taught in learning that is contained in a lesson plan.

d. Instructional Objectives; The formulation of learning objectives is a specific learning objective (an indicator of learning outcomes) obtained from the results of the objective analysis carried out at the learning problem stage.

e. Content Sequencing; At this stage, the contents of the subject matter to be taught are sorted first. According to Posner and Strike, five aspects need to be considered in sequencing the subject, namely prerequisite knowledge, familiarity, difficulty, interest, and student development. After the subject matter is sorted, the next step is to determine the initial learning strategy.

f. Instructional Strategies; The learning strategies used to describe the sequence and methods of learning to achieve predetermined goals.

g. Instructional Delivery; The method of delivery is determined based on the objectives and learning environment, which can be the classical, group, or individual in nature.

h. Evaluation instruments (test learning outcomes); are prepared based on specific learning objectives that have been formulated. The assessment criteria carried out are benchmark reference assessments so that the learning outcome tests developed must be able to measure the level of achievement of specific learning objectives.

i. Instructional Resources; Factors to consider in making learning media that will be used are commercial availability, procurement costs, time to provide it, and fun for students.

j. Revision; Revision of learning tools is intended to evaluate and improve the learning tools developed. Revision of the device is carried out through the analysis stage by experts, the results of learning simulations, the results of the trial I, and the results of trial II.

k. Formative Evaluation; Formative assessment is an assessment that is carried out after every unit of the learning process. This assessment is useful for finding weaknesses in lesson planning so that these deficiencies can be avoided before the program is widely used.

l. Planning and Project Management; Influence the success of the development design. Planning learning is a complex process that requires device developers always to pay attention to each element and continuously reassess the relationship of each part of the plan with the overall order because each element can influence the development of other elements.

m. Summative Evaluation; Summative evaluation is directed at measuring how far the primary learning outcomes are achieved at the end of all learning, it can also be a follow-up activity for students after they have completed a learning program to determine whether and how they use and apply knowledge, skills, and the attitude he learns in the learning program.

n. Support Services; Support services include the availability of budgets, facilities, materials, equipment, staff capabilities, teachers, learning designers, experts, and so forth.

The advantages of the Kemp learning model are that in this Kemp learning model, every time to take a step or procedure, there is a revision first, which is used to go to the next stage. The goal is that if there are deficiencies or errors at that stage, improvements can be made first before moving on to the next stage. At the same time, the weakness of the Kemp learning model is that Jerold E. Kemp's learning model is slightly inclined towards classical learning or learning in class (Defina, 2018). Therefore, the role of the teacher here has a significant influence because it is demanded in the framework of teaching programs, evaluation instruments, and teaching strategies.

\section{Dick \& Carey models}

Various models can be developed in organizing teaching. One of them is the Dick and Carrey learning model. The learning steps include (1) identifying the general objectives of learning, (2) carrying 
out teaching analysis, (3) identifying input behavior and student characteristics, (4) formulating performance goals, (5) developing benchmark reference test items, (6) ) developing teaching strategies, (7) developing and selecting teaching materials, (8) designing and implementing formative evaluations, (9) revising learning materials, (10) designing and conducting summative evaluations (Suryani, 2013). According to Uno (2007), in general, the use of the Dick and Carrey teaching model (Mahroji, 2015) is as follows:

a. The Dick and Carrey model consists of 10 steps. Each step is very clear about its purpose and purpose, so for novice designers, it is very suitable as a basis for studying other design models.

b. The ten steps in the Dick and Carrey model show an evident and unbroken relationship between one step and another. In other words, the system in Dick and Carrey is very concise, but its content is reliable and transparent from one order to the next.

c. The first step in the Dick and Carrey model is to identify teaching objectives. This step is very much following the curriculum, both in tertiary institutions and middle and elementary schools, especially in certain subjects that have learning objectives in the curriculum to be able to produce a learning design.

The use of the Dick and Carrey model in the development of a subject is intended so that: (a) at the beginning of the learning process, students or students can know and be able to do things related to the material at the end of learning, (b) there is a link between each component, especially strategy learning and the desired learning outcomes, (c) implementing the steps that need to be taken in planning the learning design (Faishol, 2018). The advantages of the Dick and Carrey model are as follows:

a. Every step is transparent so that it can be followed

b. Organized, effective and efficient in implementation

c. Is a model or a detailed learning plan, so that it is easy to follow

d. There is a revision in instructional analysis, which is an excellent thing because if an error occurs, changes can be made to the instructional analysis immediately before the errors in it affect the errors in the components after that

e. The Dick \& Carey model is complete in components, almost covering everything needed in a lesson plan.

The weaknesses of the Dick and Carrey model are as follows:

a. Rigid, because every step has been determined

b. Not all teaching and learning procedures can be developed according to these steps

c. Not suitable to be applied in large-scale learning

d. It was not clear when the trial should be carried out, and revision activities were only carried out after the formative test was held

e. At the stages of developing learning outcomes tests, learning strategies as well as developing and assessing learning materials, it is not clear whether there is an expert's assessment (validation).

f. There are too many procedures that must be done by the teacher in carrying out the learning process

5. Gerlach \& Ely model

Gerlach and Ely designed a learning model that is suitable for all groups, including elementary schools, as it contains a suitable strategy for students to use when receiving the material to be delivered. Gerlach and Ely 's model also stipulates the use of educational technology products as media for material delivery. This model is an attempt to describe graphically, a systematic method of planning learning. It shows an excellent overall teaching and learning process in this model despite not describing the details of each component. This model shows the relationship between one element and another and presents a pattern of sequence that can develop into a good learning process.

The advantages of the Gerlach and Ely Learning Model differ from other learning models. The most apparent difference is holding a pre-test (initial test) before teaching and learning activities. The pre-test is a stage deemed necessary because the teacher does not know the students ' characteristics. Gerlach and Ely's learning models are also very meticulous in learning activities, as evidenced by holding pre-test (initial test), learning strategies, learning groupings, and feedback. Besides having advantages, the Gerlach and Ely learning models also have a few shortcomings, including no stage to identify student characteristics to at least overwhelming the teacher in analyzing student learning needs during the learning process, and students are reluctant to express their views. Following Gerlach and Ely (Harjanto, 2010), the learning steps consist of: 
a. Formulate learning objectives; In learning objectives to formulate what abilities students must have at a certain level of learning so that after completing certain subjects, students can have predetermined abilities.

b. Determine the content of the material; The content of the material must be following the objectives to be achieved. Therefore, what will be taught to students should be selected a more specific subject.

c. Assessment of Entrepreneur Behaviors; Students' initial abilities are determined by giving a preliminary test. Knowledge of students' initial abilities is essential for teachers to be able to provide the right portion of lessons.

d. Determination of Strategy; A learning strategy is an approach that teachers use in manipulating information, selecting sources, and determining the role of students in teaching and learning activities.

e. Organization of Groups; The teacher must plan how the study group will be organized.

f. Allocation of Time; Time use plans will vary based on the subject matter, formulated objectives, available space, and others.

g. Allocation of space; Room allocation Is specified by answering whether learning objectives can be used more effectively by independent and free learning.

h. Alternative of Resources; Choosing the media is determined according to the agreed-upon student responses so that its function is not only as a stimulus for student learning stimuli.

i. Evaluation of Performance; The evaluation instrument is developed based on the formulation of objectives and must be able to measure student success correctly and effectively.

j. Analysis of Feedback; Feedback is the last stage of the development of this instructional systemfeedback data obtained from evaluations, tests, observations, and responses about instructional efforts.

The characteristics of the Gerlach and Ely learning models are as follows:

a. The creators or developers compiled logical theoretical.

b. The foundation of thinking about what and how students learn (learning objectives to be achieved)

c. The teaching attitudes necessary for the model to be implemented successfully.

d. The learning environment necessary for the learning objectives to be achieved.

\section{DISCUSSION}

The learning model is a plan or a pattern that is used as a guide in planning classroom learning. This model is a general pattern of learning behavior to achieve the expected competence/learning objectives. According to Joice \& Weil, the learning model is a pattern or plan that has been planned in such a way and is used to compile a curriculum, organize subject matter, and provide instructions to teachers in their class (Nurdyansyah \& Fahyuni, 2016). There are several learning models, namely as follows:

\section{Cooperative Learning)}

The cooperative learning model is a learning activity in groups to work together to help each other construct concepts, solve problems, or inquire. According to theory and experience so that the group is cohesive (cohesive-participative), each member of the group consists of 4-5 people, heterogeneous students (ability, gender, character), there is control and facilitation and asks for responsibility for group results in the form of reports or presentations. The cooperative learning syntax is information, strategy-briefing, forming heterogeneous groups, group work, presentation of group results, and reporting.

\section{Contextual Teaching and Learning}

Contextual learning is learning that begins with an oral presentation or question and answer (friendly, open, negotiated) related to the real world of student life (daily life modeling), so that you will feel the benefits of the material to be presented, learning motivation emerges, the world of students' minds becomes concrete. The atmosphere becomes conducive - comfortable and pleasant. Contextual learning archives are student activities, students do and experience, not just watching and taking notes, and developing socialization skills.

\section{TGT (Teams Games Tournament)}

The application of this model by heterogeneous grouping students, the assignment of each group can be the same with a different bias. After obtaining the assignment, each group worked together in the 
form of individual work and discussion. Strive for cohesive and cohesive group dynamics and a growing sense of competition between groups, a comfortable and pleasant atmosphere of discussion, such as in games, namely by the way the teacher is open, friendly, gentle, polite, and there are odorous dishes. After finishing the group work, present the group results so that a class discussion occurs.

\section{CONCLUSION}

Planning can explain as a process of preparing things to be done in the future to achieve a predetermined goal. Planning is also a managerial process in determining what to do, how to do it, and what to achieve. Achieving goals, outlines, and work programs are developed. Therefore, learning preparation is a decision -making process arising from thinking around specific learning goals and objectives, including behavioral changes and a series of activities that must be carried out to achieve such goals by using all existing potential and learning resources. Ki Hajar Dewantara said that learning was nothing but education. Learning is nothing but the purpose of education by providing knowledge or knowledge and skills, the meaning of which is the interaction of learning and teaching that takes place as a process of mutual influence between teachers and students in Indonesia, where there is a relationship or communication of interaction, namely teachers teaching on the one hand and students learning on the other. Innovative character education was pursued in response to several weaknesses in the implementation of morals and character education (character education), primarily through Religious Education and Citizenship Education. The following innovations are:

3. Character education is integrated into all subjects. The integration includes preparing values in all subjects and implementing learning activities that facilitate the application of values for all subjects in and outside the classroom.

4. Character education is also integrated into the implementation of student development activities.

5. Also, character education is carried out through management activities of all school affairs involving all school members.

\section{REFERENCES}

Afandi, M., \& Badaruddin. (2011). Perencanaan Pembelajaran. Alfabeta.

Alannasir, W. (2020). Characteristic-Based Development Students Aspect. International Journal of Asian Education, 1(1), 29-36. https://doi.org/10.46966/ijae.v1i1.18

Al-Maarij, R. (2019, April 22). Pemanfaatan Media Teknologi Informasi Dan Komunikasi Dalam Pembelajaran Fiqih di MA At-Thahiriyah Ngantru Tulungagung [Skripsi]. IAIN Tulungagung. https://doi.org/10/10/DAFTAR\%20PUSTAKA.pdf

Ananda, R. (2019). Perencanaan Pembelajaran. Lembaga Peduli Pengembangan Pendidikan Indonesia (LPPPI).

Astuti, I. A. D., Sumarni, R. A., \& Saraswati, D. L. (2017). Pengembangan Media Pembelajaran Fisika Mobile Learning berbasis Android. Jurnal Penelitian \& Pengembangan Pendidikan Fisika, 3(1), 57-62. https://doi.org/10.21009/1.03108

Baderiah, B., \& Ilham, D. (2019). The Implementation Of Pre Merriage Course At KUA Wara Palopo City. IAIN Palopo. http://repository.iainpalopo.ac.id/id/eprint/934/

Baharuddin, A. Z. (n.d.). Digital Revolution and the Renewed Mechanism of Religious Discourse.

Defina, D. (2018). Model Penelitian dan Pengembangan Materi Ajar BIPA (Bahasa Indonesia bagi Penutur Asing). Indonesian Language Education and Literature, 4(1), 36-51. https://doi.org/10.24235/ileal.v4i1.3012

Diah, M. (2020). Pengelolaan Pembelajaran IPA Berbasis Literasi Sains di Smplb Negeri Ungaran-UMS ETD-db. http://eprints.ums.ac.id/80630/

Dianti, P. (2014). Integrasi Pendidikan Karakter Dalam Pembelajaran Pendidikan Kewarganegaraan Untuk Mengembangkan Karakter Siswa. Jurnal Pendidikan Ilmu Sosial, 23(1), Article 1. https://doi.org/10.17509/jpis.v23i1.2062 
Faishol, R. (2018). Pengembangan Paket Pembelajaran Ilmu Pengetahuan Sosial (IPS) Kelas IV Menggunakan Model Dick, Carey \& Carey di SD Negeri 2 Tamanagung. Tarbiyatuna: Kajian Pendidikan Islam, 2(2), 31-49.

Fathurrohman, M. (2017). Belajar dan Pembelajaran Modern: Konsep Dasar, Inovasi dan Teori Pembelajaran (I). Garudhawaca.

Fitriyadi, H. (2013). Integrasi Teknologi Informasi Komunikasi dalam Pendidikan: Potensi Manfaat, Masyarakat Berbasis Pengetahuan, Pendidikan Nilai, Strategi Implementasi dan Pengembangan Profesional. Jurnal Pendidikan Teknologi Dan Kejuruan, 21(3), Article 3. https://doi.org/ 10.21831/jptk.v21i3.3255

Fitriyani, H., \& Rosalia, L. (2018). Pengembangan Media Video Tutorial untuk Mengenalkan Treatment Mengelola Emosi Marah Pada Peserta Didik Kelas X di SMK Cipta Karya Jakarta. INSIGHT: Jurnal Bimbingan Konseling, 7(2), 147-153. https://doi.org/10.21009/INSIGHT.072.04

Harjanto, H. (2010). Perencanaan Pengajaran. Rineka Cipta.

Hendrowati, T. Y., \& Suningsih, A. (2018). Mengapa Skenario Pembelajaran Perlu Pendidikan Karakter? International Journal of Community Service Learning, 2(1), 34-40. https://doi.org/10.23887/ ijcsl.v2i1.12889

Hisbullah, H. (2020). Implementasi Manajemen Pembelajaran Kurikulum 2013 di MI Darul Khaeriyah Kecamatan Suli Kabupaten Luwu. Didaktika: Jurnal Kependidikan, 9(1), 9-24.

Hisbullah, H., \& Firman, F. (2019). Penerapan Model Pembelajaran Snowball Throwing dalam Meningkatkan Hasil Belajar Ilmu Pengetahuan Alam di Sekolah Dasar. Cokroaminoto Journal of Primary Education, 2(2), 100-113. https://doi.org/10.30605/cjpe.222019.231

Ilham, D. (2020). Persoalan-Persoalan Pendidikan dalam Kajian Filsafat Pendidikan Islam. Didaktika: Jurnal Kependidikan, 9(2), 179-188.

Ingtias, R. S. A. (2016, July 29). Profil Kompetensi Literasi Sains Siswa Berdasarkan Programme For International Student Assesment (PISA) pada Konten Biologi (Kuasi Deskriptif Siswa Kelas IX SMP se-Kecamatan Kedaton di Bandar Lampung) [Skripsi]. Fakultas Keguruan dan Ilmu Pendidikan. http://digilib.unila.ac.id/23434/

Majid, A. (2014). Belajar dan Pembelajaran Pendidikan Agama Islam. Rosda Karya.

Nurdyansyah, N., \& Fahyuni, E. F. (2016). Inovasi Model Pembelajaran Sesuai Kurikulum 2013. Nizamia Learning Center. http://eprints.umsida.ac.id/296/

Pane, A., \& Dasopang, M. D. (2017). Belajar dan Pembelajaran. FITRAH:Jurnal Kajian Ilmu-Ilmu Keislaman, 3(2), 333-352. https://doi.org/10.24952/fitrah.v3i2.945

Prawiradilaga, D. S. (2009). Prinsip Desain Pembelajaran. Prenada Media.

Qasim, M. (2016). Perencanaan Pengajaran dalam Kegiatan Pembelajaran. http://journal.uinalauddin.ac.id/index.php/diskursus_islam/article/view/7365

Rosyadi, Y. I., \& Pardjono, P. (2015). Peran Kepala Sekolah sebagai Manajer dalam Meningkatkan Mutu Pendidikan di SMP 1 Cilawu Garut. https://journal.uny.ac.id/index.php/jamp/article/view/ $6276 / 6343$

Rusman, R. (2012). Model - Model Pembelajaran Mengembangkan Profesionalisme Guru. Rajawali Pers.

Sari, B. K. (2017). Desain Pembelajaran Model ADDIE dan Implementasinya dengan Teknik Jigsaw. 87102. http://eprints.umsida.ac.id/332/

Shawmi, A. N. (2015). Pendidikan Kecakapan Hidup (Life Skill) dalam Pembelajaran Sains di SD/MI. Terampil: Jurnal Pendidikan dan Pembelajaran Dasar, 2(2), 240-252. https://doi.org/ 10.24042/terampil.v2i2.1295 
Sijatri, P. E. (2010). Manajemen program pengembangan lingkungan permukiman berbasis komunitas (studi di Desa Jendi Kecamatan Selogiri Kabupaten Wonogiri). https://digilib.uns.ac.id /dokumen/13913/Manajemen-program-pengembangan-lingkungan-permukiman-berbasiskomunitas-studi-di-Desa-Jendi-Kecamatan-Selogiri-Kabupaten-Wonogiri

Simbolon, N. (2014). Faktor-Faktor Yang Mempengaruhi Minat Belajar Peserta Didik. Elementary School Journal PGSD FIP UNIMED, 1(2), Article 2. https://doi.org/10.24114 /esjpgsd.v1i2.1323

Situmorang, R. P. (2016). Integrasi Literasi Sains Peserta Didik dalam Pembelajaran Sains. Satya Widya, 32(1), 49-56. https://doi.org/10.24246/j.sw.2016.v32.i1.p49-56

Suryani, N. (2013). Pengembangan Model Internalisasi Nilai Karakter dalam Pembelajaran Sejarah melalui Model Value Clarification Technique. Paramita: Historical Studies Journal, 23(2), Article 2. https://doi.org/10.15294/paramita.v23i2.2674

Suryapermana, N. (2017). Manajemen Perencanaan Pembelajaran. Tarbawi: Jurnal Keilmuan Manajemen Pendidikan, 3(02), 183-193. https://doi.org/10.32678/tarbawi.v3i02.1788

Trianto. (2013). Mendesain model pembelajaran inovatif-progresif: Konsep, landasan, dan implementasinya pada kurikulum tingkat satuan pendidikan (KTSP). Kencana.

Trianto, A.-T. (2017). Mendesain Model Pembelajaran Inovatif, Progresif, Dan Konteksual. Prenada Media. 